\title{
Portrait of a Profession in Paralysis
}

\section{Robert W. Gordon*}

Reading Deborah Rhode's book on the legal profession is a profoundly depressing experience. This is precisely because of the book's understatement. Unlike many of the recent jeremiads lamenting the fall of the profession from a golden age of ethical practice and public service, In the Interests of Justice is far from an undiscriminating broadside against the bar and its works. Rhode strives to be restrained, temperate and discriminating in her critiques. Unlike most of the political and media critics of the profession, she relies on a substantial body of sober research on lawyers and their work rather than on anecdotal horror stories. Indeed she uses this research to defend lawyers against some of the more common attacks on them, such as that criminal defense lawyers regularly bring about the release of dangerous criminals on "technicalities," and that personal injury lawyers are seriously damaging the American economy by deluging businesses with frivolous lawsuits. (The real scandals, as she points out, are that most accused criminals get no effective representation at all and that most valid personal injury claims never reach the tort system and remain uncompensated.) Nor is her book purely destructive, an indictment without remedies. Although often acerbic, her tone is detached and diagnostic rather than polemical or accusing. She has many practical proposals for reform, which on the whole are modest, incremental, sensible, and entirely feasible.

So why is this book so depressing? For three reasons. First, because when you add up all of Rhode's restrained, discriminating, understated critiques, they sum to a notably bleak total picture of the practices, attitudes, and working styles that lawyers have come to accept as regular components of their jobs. Second, and more disturbing, her book draws a portrait of a profession so habituated to these practices and the mentalities that sustain them, so prone to denial about some of the resulting pathologies, or else so self-interested, fragmented, timid, or paralyzed, that it is most unlikely to take any collective action to reform them, and likely if anything to resist and effectively defeat any outside agencies' efforts at reform. Third and most sadly, the legal profession Rhode portrays is one that seems to have forgotten its dreams of greatness-its historic conviction that American lawyers, as much as or more than any other

- Chancellor Kent Professor of Law and Legal History, Yale University. 
occupational group or association, could assume a great constructive leadership role in the state and society.

Let me say something briefly about each of these themes:

\section{HABITUAL PRACTICES AND ATTITUDES}

Here Rhode covers ground that is mostly familiar to observers of the legal profession. But by bringing together so much work into a general synthesis, she enables the reader to survey the whole wide terrain of the problem. To summarize her findings in a nutshell, they are that lawyers have a core set of commitments, certain basic hard nuggets of professional conventional wisdom. Mostly they take these for granted, but, if they have to, they justify those commitments, and the habitual practices that have evolved to serve them, by reference to their socially beneficial aggregate effects. The trouble with these commitments and practices and their justifications is that in many situations it is plainly demonstrable that the practices have very bad social effects, sometimes effects subverting the very values-justice, truth, individual dignity and freedom, and public welfare-they are supposed to serve. Moreover, whenever acting on even their best core commitments starts to seriously grate against lawyers' self-interest, they are prone to compromise or abandon the commitments. To illustrate:

\section{A. Lawyers' Prime Core Commitment Is to the Virtue of the Role of the Zealous Advocate}

Lawyers' prime core commitment is to the virtue of the role of the zealous advocate. That role is justified by its supposed benefits in (a) serving an overall process (the adversary system) that promotes truthful fact-finding, and (b) guarding the rights, autonomy, and dignity of clients-protecting them from harm and promoting their freedom to pursue their freely-chosen life projects.

As Rhode, following many previous critics, points out, the chief problem with justification (a) is that most people are priced out of the adversary system and can afford only weak advocates or none at all. ${ }^{\text {Even }}$ with both sides wellrepresented, adversary advocacy in actual fact often operates to obscure truth. Effective resistance to discovery keeps essential evidence out of the case. Effective cross-examination discredits truthful witnesses. Adversarial presentation of expert testimony, using distortion to cancel out distortion, produces more confusion than light.

The chief problems with justification (b) are that it fails to distinguish exercises of autonomy that deserve protection from those that do not, and ignores harms that clients, assisted or protected by lawyers, may inflict on

1. DEBORAH RHODE, IN THE INTERESTS OF JUSTICE: REFORMING THE LEGAL PROFESSION $55-56,207-08(2000)$. 
others or on society. It does not weigh such harms to others in the balance and discount them against the client's interests; it willfully ignores them, treating them as literally irrelevant to the justice of the lawyer's representation. It is easy to understand why a lawyer may justly object to the introduction of evidence against her client seized in an illegal search: Her objection helps (however clumsily and indirectly) to preserve all our interests in constitutionally scrupulous police procedure, in not having our doors broken down at three in the morning without probable cause certified by a judge. It is far harder to understand why a lawyer for a savings-and-loan company that is gambling recklessly with taxpayer-insured deposits may justly help that company obscure the riskiness of its loans from regulators whose job is to protect the public funds; or, to take an example currently in the headlines, why lawyers for an energy company may justly help the management set up hundreds of offshore havens that avoid its having to pay taxes, or create hundreds of outside partnerships whose evident function is to keep debts and losses off the books and hidden from investors and employees, or make offerings of special opportunities to select rich investors with access to company financial information kept secret from the investing public. Even if all these schemes should turn out to be (at least arguably) technically legal, what values of overall human flourishing or individual self-fulfillment or economic efficiency are served by helping clients promote them? Freedom generally is a good thing, to be sure; but there is no virtue per se in action, any old action, that is freely chosen, if it is likely to bring destruction in its wakeincluding, in these examples, harm to the real clients themselves, not their incumbent managements but the long-term corporate entities and their constituent stake-holders.

At any rate, the norm of all-out, go-for-broke, damn-the-torpedoes zealous advocacy, in actual practice, turns out to be binding only so long as it is profitable to the advocate. If it starts to cost too much in foregone fees, or shares of contingent settlements, or beneficial continuing relations with judges or prosecutors, it tends rapidly to shrink to the vanishing point. Lawyers who swear their ethic is to defend clients to the death apparently see no problem in routinely padding their bills to those same clients. ${ }^{2}$ Even the bar's most sacred ethics rules of confidentiality are suspended if the lawyer gets into a fee dispute with a client. ${ }^{3}$

\section{B. Lawyers Are Committed to the Norm of Nonaccountability}

Lawyers are also committed to the related norm of nonaccountability- that they are not morally responsible for the actions of clients that they help defend. The main justification for this norm is that everyone is entitled to

2. Pp. $168-83$.

3. See Model Rules of Prof'L CONDUCt R. 1.6(b)(2). 
representation, and that lawyers must not be tarred with the sins of clients, lest that lead them to ignore unpopular clients. Taking on a client should not imply adopting his cause. But this norm, as Rhode says, is coupled with another that deprives it of most of its force: that lawyers may decline clients who are repugnant to them (or for any other reason). In actual effect the norm only encourages lawyers to take on unpopular clients who are also rich; the bar has "generally avoided social pariahs with shallow pockets" - such as AfricanAmericans in the age of Jim Crow or Communists in the 1950s or all but wealthy criminal defendants in any period. A profession seriously committed to seeing that every side was represented would make itself a common carrier or public utility or adopt something like the (widely evaded but still aspirationally vital) British barrister's "cab-rank rule," prescribing that lawyers must take on the next client who asks for their services, or at least maintain a rotating pool of lawyers of last resort to take the cases nobody else wants.

\section{Lawyers Hold (Selectively) Sacred the Norm of Confidentiality}

Lawyers hold the norm of confidentiality so sacred that they enact rules forbidding them to disclose client secrets even when concealment is likely to cause serious harm (short of serious bodily harm or death). The rationales for this norm are that, in the case of past conduct, the client must trust the lawyer enough to give him the facts needed to present all legal defenses, and, in the case of future conduct, the lawyer whose client trusts him enough to disclose his plans will be able to prevent the harms by advising his client to desist.

The problems with these rationales are that (a) there is little evidence that exceptions to confidentiality rules significantly inhibit clients' willingness to talk to their lawyers; (b) lawyers in practice often try very hard not to find out what clients are up to, so that they will not have to face ethical dilemmas in presenting defenses or advising clients; and (c) judging by many examples of recent corporate misconduct, lawyers who are told of clients' harmful behavior or plans frequently neither try to advise clients to desist nor recognize any obligation to do so. Confidentiality thus in many representations turns out to be a device that lawyers use to facilitate clients' harmful behavior rather than prevent it. Perhaps the most dramatic recent example comes from the tobacco industry, whose lawyers advised putting the industry's entire scientific research program on the effects of tobacco on health under the general counsel's office, so that counsel could protect unfortunate research results from disclosure by invoking lawyer-client privilege, and so that the companies could continue to tell regulators and the public that they believed smoking was nonaddictive and safe..$^{5}$

4. P. 58.

5. See Stanton A. Glantz, John Slade, lisa A. Bero, Peter Hanauer, \& Deborah E. BARNes, THE CigaretTe PAPERS 235-338 (1996). 


\section{Lawyers Are (Rhetorically, if not always Practically) Committed to Self- Regulation}

Next to zealous and loyal client service, the profession's most fervent commitment is to self-regulation. The theory behind self-regulation is that the quality of professional services, requiring as they do complex technical knowledge and discretionary judgment, cannot be reliably evaluated by clients or by lay auditors or regulators. Only professional peers have the necessary cognitive capacity and the appropriate ethical orientation to client and public service. An independent bar is especially important so that it can serve clients and provide public legal advice (on legislation and law reform) free from the domination of the state, powerful private factions, or the financial pressures of the market. In return for this institutional autonomy and monopoly power over licensing and discipline, the profession undertakes to inculcate norms of quality and ethics, and to sanction errant members.

Here again the profession's experience undermines its claims. As an effective self-regulator, as Rhode points out, the bar has spectacularly failed to do its job. ${ }^{6}$ In most states it does not finance or staff more than a tiny fraction of the administrative machinery that would be needed to handle client complaints effectively or more pro-actively investigate systemic abuses and engage in rulemaking. Self-regulation has become more a means to protect lawyers from complaining clients than clients (or other adversely affected groups) from incompetent or dishonest lawyers. Many people argue this failure is entirely predictable, given any profession's obvious self-protective impulses and blinders of sympathy and partiality. But lawyers' self-regulation must surely represent something of an extreme of professional laxity: The bar has never developed any institutions for monitoring practitioners' competence after the (very weak and unreliable) initial bar exam. ${ }^{7}$ Lawyers practicing in firms, like doctors in hospitals, are under some degree of collegial and hierarchical supervision (though this tends to become very loose once the lawyer is a partner, especially if he has a big business book); lawyers on their own are subject to none. Not surprisingly, the bar has been forced gradually to submit to the supervision of other regulators: courts, legislatures, administrative agencies, and malpractice plaintiffs and insurers.

And what of the claim that self-regulation is needed for independence? Here too the history is discouraging. Until the 1970s the bar strenuously resisted state-financed legal services on the ground that lawyers' independence would be compromised, but did almost nothing itself to see that poor people got lawyers. Since then, by default, governments have come to be the primary payers for legal services for the indigent, public defender programs, and state-

6. Pp. 158-62.

7. The only post-bar institution that might possibly be considered to fulfill such a role is the truly laughable Continuing Legal Education (CLE) requirement. See Pp. 156-58. 
reimbursed, court-appointed counsel. Since then also, the bar to its credit has strongly supported these programs; but the subsidies are so stingy and saddled with restrictions as seriously to compromise the independence and effective advocacy of state-financed attorneys. The bar's traditional aspirations for independence from powerful private factions have come to an even sadder end. The business bar at first fought, then gradually acquiesced in, and in recent years has finally come to enthusiastically embrace, its subservience to its corporate clienteles. Instead of striving to preserve criteria of professional virtue independent of the marketplace, lawyers have eagerly adopted profitseeking as their primary business and profits-per-partner as their primary measure of success.

\section{RESISTANCE TO REFORM}

As I said earlier, one of the great virtues of Rhode's book is that for every problem its author identifies, she proposes solutions-some very general, others very concrete. Like her descriptions of the problems, her reform proposals are culled from the now-ample fund of recent scholarship on the profession, much of it her own scholarship. To help serve unmet legal needs, she favors opening up the lawyer's monopoly to lay advisers, paralegals, and new specialists requiring shorter training than lawyers (who now need seven years of higher education and accumulate $\$ 100,000$ or more of debt in law school alone). She would also loosen rules restricting practice so that lawyers could practice across state lines and in partnership with nonlawyers. She would promote organizations for delivering legal services that would offer informal alternatives to litigation. Though she believes in increasing competition, she is not a simple-minded free-marketeer, and recognizes that if new providers are allowed to compete with lawyers, they will need to be regulated to protect clients and-an important theme in her work-affected third parties. Among regulatory approaches, she favors consumer protection regimes emphasizing openness and accountability, especially of fee arrangements, and oversight and enforcement by independent outside bodies (regulatory commissions and consumer organizations), or mixed bodies of lawyers and laypersons, over the bar's self-regulation (or rather nonregulation). She wants the bar-and also law faculties-to adopt mandatory pro bono requirements to contribute either services or cash to legal services for the indigent. ${ }^{8}$

Besides more competition and more effective regulation of the profession, she favors some changes in its basic norms. The zealous-advocacy norm, she rightly says, over-generalizes from criminal defense to contexts where there are few or no checks on adversary excesses.9 Lawyers can't escape moral responsibility for actions that injure adversaries, third parties, or the reliable

8. Pp. 209-13.

9. P. 55. 
operation of the justice system by claiming that their hired-gun role fits into an overall system that insures fairness. In many contexts no such system is functioning because relevant parties are represented weakly or not at all, and umpires are not present or too weak to enforce the rules. (Discovery, a process at the heart of adversary litigation, is one such context.) She dislikes the profession's attempt to regulate by one-size-fits-all rules; and would prefer discretionary standards, which would be applied as more particular bestpractice rules and guidelines to particular fields of practice by specialists and regulators in those fields. ${ }^{10}$

Of course critics could reasonably disagree about the merits of Rhode's proposals. Some seem a bit bureaucratic, like the use of "diversity training and consultants" to improve law firms' records of hiring and retaining nonwhitemale lawyers." Others seem too modest in scale to address the gravity of the problems she identifies. Her account makes pretty clear that many of the problems with access to the legal system result from the fact that the system of litigation is much too complex and expensive to process most of the claims brought to it. What is required for many kinds of claims and disputes is not merely more paralegals or $\mathrm{ADR}$ alternatives, but the displacement of some disputes from the courts into new specialized tribunals using simple procedures and permitting lay or (as is already proliferating in our regular courts) self-help advocacy. ${ }^{12}$ Still other of her proposals seem a bit over-general, such as those urging lawyers to make more contextualized moral judgments. Our profession has become so used to treating ethical decision-making as following rules that contextual guidelines will probably have to take fairly specific shape, and involve either the threat of liability or the promise of safe-harbor immunity from liability, to get lawyers to take them seriously. But most of her reform proposals seem sound and sensible, and all of them are good starting-points for debate.

Unfortunately Rhode, speaking with the authority of one who has been involved in bar reform efforts for many years, also gives her readers many

10. Pp. 66-67, 71 .

11. P. 47.

12. I don't think Rhode would disagree with this assessment. See Pp. 132-35. After 1910 workers' compensation claims were shifted out of the tort system to such tribunals; and more recently family courts in many jurisdictions have shifted uncontested divorces into simplified pro se proceedings. Another development is more sinister: Employers and commercial sellers have increasingly shifted disputes out of the courts by forcing employees and consumers to agree to contracts mandating arbitration. Such experiments have turned out to be flawed in various ways, especially the recent contract-mandated compulsory arbitration panels, which tend to be dominated by arbitrators whose incentives are to favor the industry side, and which at best do only individual justice, excluding the class actions and structural remedies that are often the most effective against systemic abuses. In general, very informal dispute-settlement means such as mediation do not work well to solve the problems of weak parties facing strong ones. But tribunals can be well-designed and fairly administered, as is apparently the case with the various European tribunals set up to handle claims of unjust dismissal from employment. 
reasons to doubt that most lawyers are ready to discuss basic reforms. This is not, generally, because lawyers are happy with the status quo. Many law firm lawyers are unhappy with the pressures and time demands of their work, which increasingly squeeze out all space for family and personal life, pro bono work, and public service-the things that are most necessary to put together a meaningful life as well as to satisfy the public obligations of the profession. But firm managers are not willing, or able, to overcome the collective-choice obstacles to realizing goals besides money-making, to sacrifice some income to achieve saner practice conditions. The pressures bear most intensely, of course, on women, who are forced out of law practice in disproportionate numbers. Many firms worry about this too, but few worry enough to institute flexibletime options that will not derail the careers of women attorneys. Many lawyers are also disturbed about the public reputation of their profession (which seems to be lower now than it has ever been), but attribute nearly all their image problems to bad public relations and misunderstanding of the lawyer's role.

Similarly, lawyers acknowledge that abuses are widespread in certain areas of practice, such as civil discovery, but invariably they blame someone else. The plaintiff's bar blames the defense bar, and vice-versa. Judges blame lawyers for stretching the rules; lawyers blame judges for not enforcing them. Corporate lawyers blame the plaintiff's personal injury bar for bringing frivolous claims; plaintiffs blame the defense bar for obstructing just claims. Neither side wants to address the appalling administrative costs of litigation, which keep most claims out of the system completely, or jointly-caused problems such as collusive settlements of class actions.

After the collapse of the savings-and-loan industry, which cost American taxpayers $\$ 500$ billion or more, a federal judge famously asked the reasonable question, "Where were the[] [lawyers]?", ${ }^{13}$ while bankers such as Lincoln Savings \& Loan's Charles Keating were investing depositors' governmentinsured money in dubious self-dealing real-estate ventures. The answer, charged the Office of Thrift Supervision ("OTS") (set up to handle the

13. As Judge Sporkin stated in Lincoln Savings \& Loan Ass'n v. Wall, 743 F. Supp. 901, 919-20 (D.D.C. 1990):

Keating testified that he was so bent on doing the "right thing" that he surrounded himself with literally scores of accountants and lawyers to make sure all the transactions were legal. The questions that must be asked are:

Where were these professionals, a number of whom are now asserting their rights under the Fifth Amendment, when these clearly improper transactions were being consummated?

Why didn't any of them speak up or disassociate themselves from the transactions?

Where also were the outside accountants and attorneys when these transactions were effectuated?

What is difficult to understand is that with all the professional talent involved (both accounting and legal), why at least one professional would not have blown the whistle to stop the overreaching that took place in this case. 
aftermath of the debacle), was that the lawyers for the thrifts, though wellaware of the riskiness of the deals and the misleading claims their clients were making about them, were hyping them to bank regulators as "exceptionally sound" while setting up procedural obstacles to examiners' scrutiny of the books and helping thrift clients lobby for weakened oversight. OTS later severely sanctioned one of the law firms involved. One might have supposed that this experience would have convinced the relevant segments of the profession to re-examine practices that had facilitated so spectacularly disastrous a collapse. If the lawyers were just doing their jobs, might there not be something amiss-given the disaster that they could have helped to prevent-with how they defined their jobs? But in fact, every bar group that looked into the matter found the lawyers were behaving appropriately, were outraged only that the OTS had imposed severe sanctions (an asset freeze) on a law firm, and did not even begin to address the important question, which was how lawyers might change their practices so that the next time around they could do more to prevent such problems. ${ }^{14}$

Similar questions will soon be asked, or should be, about the role of lawyers in the collapsed Enron Corporation. Exactly what the lawyers for the principals did is still murky and likely to remain so, but as I write congressional and Enron internal inquiries and the press are reporting the following:

- An Enron executive, Sherron Watkins, warned company chairman Kenneth Lay that the company was about to "implode in a wave of accounting scandals" because of dubious accounting by Enron's auditors, Arthur Andersen, for the many limited-partnership investment deals it had used to keep debt off the parent company's books and inflate its earnings. She said that many senior executives had complained loudly about these practices, that the company was "crooked," and that the side deals either had to be undone (if not too late to escape detection) or disclosed. She advised the chairman to ask an independent outside law firm to investigate, noting that Enron's regular law firm of Vinson \& Elkins ("V \& E") should be disqualified because it had signed off (given "true sale" opinions) on some of the deals and had a conflict of interest. ${ }^{15}$ Contrary to her advice, Lay did ask V \& $E$ to review the transactions but to stop short' of looking into Andersen's treatment of them. V \& E, overlooking its own conflict and the patent contradiction in Lay's instructions to avoid looking at the very source the whistleblower had identified as the cause of the problem, duly reported back that the transactions seemed fine-because the auditor had, after all, approved them (!). The lawyers then warned that "the bad cosmetics" of the partnerships could result in "a serious

14. For this story in detail, see William H. Simon, The Kaye Scholer Affair: The Lawyer's Duty of Candor and the Bar's Temptations of Evasion and Apology, 23 Law \& Soc. Inquiry 243 (1998).

15. Text of Letter [by Sherron Watkins] to Enron's Chairman After Departure of Chief Executive, N.Y. TIMES, Jan. 16, 2002, at C6. 
risk of adverse publicity and litigation," but concluded with the advice that no further investigation was necessary (!). ${ }^{16}$

In short, V \& E gave Chairman Lay the whitewash he asked for, with a caveat phrased so they. could later claim that they had warned of possible trouble. In hindsight their most dubious advice was that no further inquiry was warranted. The lawyers could not possibly know enough to say that, because they had kept their own review out of the danger area. Their advice may have satisfied Kenneth Lay, but Lay was not their client. Enron the company was, including its hapless stockholders. In general the Enron lawyers' disposition, like the accountants', seems to have been to try to preserve plausible deniability, by refraining from asking hard questions that might yield awkwardly unwelcome revelations that might have to be reported to the directors, shareholders, or regulators.

- On hearing of the Watkins letter, Andersen retained an outside law firm, Davis Polk \& Wardwell, for advice about possible future Enron-connected legal problems. The Watkins letter also prompted several senior Andersen partners including David Duncan, head of Andersen's Enron engagement team, to start a series of meetings by conference call. In these conference calls Nancy Temple, an in-house lawyer for Andersen, pointedly asked Duncan, "How are you on compliance with the document retention policy on Enron?" On October 12,2001 , after Andersen had started to worry enough about exposure to retain outside counsel, Temple sent Andersen partners an e-mail emphasizing the importance of compliance with the "document retention policy." This instruction was ambiguous, since, Andersen spokesman say, the "policy" calls for the destruction of notes and working papers used to prepare audit reports, as well as the retention of final papers. (Andersen spokesmen also say that periodic announcements of the "policy" are routine company practice, but this appears not to be true, since nobody recalls ever seeing one before.) It is, however, clear that once a firm has been served with subpoenas by regulators or plaintiffs, it must take steps to preserve all relevant documents, including background notes and drafts. By October 19 it was already clear that the SEC had begun an informal investigation and subpoenas would soon be coming. Nonetheless a team headed by Duncan started shredding Enron-related documents. A subpoena from the SEC did arrive on November 8, and on November 9 lawyer Temple finally issued orders to preserve all documents. ${ }^{17}$

Duncan, before he invoked his Fifth Amendment rights and stopped talking, said he shredded the documents on advice of counsel. ${ }^{18}$ That is, he

16. Jim Yardley \& John Schwartz, Legal Counsel in Many Ways Mirrors Client, N.Y. TIMES, Jan. 16, 2002, at C6.

17. Excerpts from a House Hearing on Destruction of Enron Documents, N.Y. TMES, Jan. 25, 2002, at C8 (reporting statements of Rep. James C. Greenwood and Arthur Andersen official Dorsey L. Baskin).

18. Richard A. Oppel, Jr., Enron's Collapse: The Overview; Auditor Received Warning on Enron Five Months Ago, N.Y. Times, Jan. 16, 2002, at Al. 
interpreted Temple's questions and e-mail as pointed instructions from house counsel, wearing only the thinnest fig leaf of cover as company "document retention [sic] policy," to start shredding Enron records. How else indeed could he have interpreted it? Temple's memo was clearly not the "routine" reminder that Andersen now incredibly claims it was, and it came in a period of crisis meetings when the firm was expecting subpoenas to arrive at any moment. In those circumstances surely the only proper advice for a lawyer to have given about Enron-related documents was an explicit instruction to preserve all of them. What was the advice of outside counsel, the Davis Polk firm? Did they inspire Temple's mysterious and ambiguous instruction on document "retention"? Why, with SEC investigations already started and subpoenas pending, did they wait (as apparently they did $^{19}$ ) until November to advise Andersen to save all documents? Surprisingly, Andersen asked Davis Polk to conduct its internal investigation of document shredding. ${ }^{20}$

- One of Enron's practices now most sharply challenged was that of offering select groups of rich investors special opportunities, through Enron's off-the-books partnerships, to profit from confidential information not available to ordinary shareholders. It is elementary that the main abuses that the Securities Acts of 1933 and 1934 were designed to prevent were those of insiders trading on information not available to the public. What made Enron's offerings possible were rules requiring investment bankers to set up Chinese walls prohibiting disclosure of confidential information. The purpose of those rules is to prevent bankers from profiting on inside information on deals they are financing. Enron used them for the reverse purpose, to create investment vehicles giving an information advantage to insiders. Also, since the partnerships were managed by Enron's chief financial officer, and created gross potential conflicts between his roles as general partner and Enron CFO, Enron obtained a waiver of the conflicts from the Enron Board.21

We do not know yet what role lawyers played in these transactions and the waiver, but presumably they gave opinions certifying their legality and may even have helped dream some of them up.

- An important job of outside counsel to a public corporation is to prepare proxy statements disclosing the company's financial position to investors. The report of the internal investigation commissioned by Enron's board of directors (the Powers Report) describes how V \& E avoided disclosing the fact that Andrew Fastow, Enron's chief financial officer who was also the manager of the "related-partner-entities" that the company set up to keep its debts and losses off the books, had arranged to be generously compensated by those

19. Susan Schmidt, Prosecutors, FBI Pore over Enron's Books, WASH. POST, Jan. 30, 2002, at A6.

20. Reed Abelson \& Jonathan D. Glater, Enron's Many Strands: The Auditor, N.Y. TMES, Feb. 3, 2002, §1, at 27.

21. For a description of these transactions, see Diana B. Henriques \& Kurt Eichenwald, A Fog over Enron, and the Legal Landscape, N.Y. TIMES, Jan. 27, 2002, § 3, at 1. 
entities. SEC rules state that disclosure is required "where practicable" of the amount of such a party's interest in such transactions; but Fastow had a "strong desire" to avoid disclosure. $22 \mathrm{~V} \& \mathrm{E}$ accommodated that desire by reasoning that, since it was uncertain how much Fastow would ultimately earn from the transactions, Enron did not even have to disclose what he actually had earned. ${ }^{23}$

In these actions the lawyers seem to have been operating, to put it generously, at the farthest possible boundary of respectable practice. The lawyer as advocate in an adversary proceeding is obviously entitled to urge on a court or agency an adventurous interpretation of law. The parties can argue about it in open proceedings on a record shared by all parties, and the tribunal can make an authoritative decision. The situation is very different when the lawyer is counseling his client with respect to future action. No adverse party is present to challenge an aggressive interpretation and no umpire to rule on its validity. Especially if legal advice is unlikely ever to be tested, it should be well on the safe side of legality, prudence, and protection of relevant interests besides management's. When the V \& E lawyers approved the Enron special offerings and the board's waiver of the CFO's conflicts in advance, and when they failed to disclose in proxy statements Fastow's personal financial interest in the related-party transactions or even to ask enough questions to find out how extensive it was, they must have known that their actions, even if by some strained though (possibly) technically legal argument, effectively thwarted the basic objectives of the securities laws. And their compliance with the wishes of Enron's officers was, once again, at the ultimate expense of their real client, Enron as an entity with a hope of a long-term future.

Now it is too soon to tell what will happen to all the players in the EnronAndersen mess, though it seems quite likely that many of them, including some of the lawyers, will face hefty civil and criminal liabilities. I can predict with a mournful certainty, however, that most lawyers and bar groups will assert repeatedly and defiantly that all the lawyers involved conducted themselves properly and that their conduct raises no serious questions about the ethics of their roles. If, by any chance, some lawyers' conduct is found to be beyond the pale, it will be dismissed as an aberration rather than a symptom of a larger problem.

The ABA recently had a chance to address the general problem of how lawyers should respond to warning signs of client fraud in the draft revision of

22. Williams C. Powers, Chair, Raymond S. Troubh \& Herbert S. WINOKUR, JR, REPORT OF INVESTIGATION BY THE SPECIAL INVESTIGATIVE COMMITTEE OF THE BOARD OF DIRECTORS OF ENRON CORP. 187 (2002)

23. Id. at 184-91. Fastow's self-dealing inspired one of the few relatively good stories to have surfaced about Enron's lawyers. An inside lawyer for the company, Jordan Mintz, was worried enough about the reporting of the related-party transactions to ask another outside law firm for an independent opinion. But after hearing from that firm that Enron should clean up its act in future disclosures, Mintz was advised by superiors to drop the matter and did not pursue it. 
its ethics rules. The ethics commission reformers succeeded after considerable struggle in recommending a very modest change: adding knowledge that the client was about to commit fraud to the grounds-which now include only knowledge that the client may cause imminent death or substantial bodily harm-that would permit lawyers to reveal client confidences to authorities or affected parties. At the ABA's annual meeting the membership, yet again, rejected the changes. ${ }^{24}$ This outcome is really too bad, because the change, though hardly a comprehensive attempt to clarify what lawyers should do when they get warning signals that their clients are engaged in fishy business, would have given lawyers for errant clients a tiny bit of extra leverage to back up advice to clients to clean up their acts. Lawyers strenuously resist any suggestion that their job is to be "cops" or "regulators" or to "enforce" the law. But why not the more modest role of helping to ensure in advance that clients comply with the law; or at least of refraining from lending such aggressive assistance to them in bending the law, avoiding detection, and obstructing enforcement that they prevent others from enforcing it and thus effectively nullify the law? ${ }^{25}$ The role of lawyer as corporate adviser needs a thorough rethinking that the bar, judging from its record, is unlikely to undertake.

Rhode's explanation, which seems right to me, for this apologetic mentality is not that lawyers are morally lax people, or even that the bar is invariably and ineradicably conservative and incapable of reform. Lawyers have given their energy to reforming the profession, legal procedures, judicial selection, and ethics in the past, and the reforms have not been all self-serving by any means. Though its record on these issues is spotty, the organized bar more than most social institutions has acted as a political force for the values of legalism, due process, and the rights of minorities and dissenters. It has tried to rid judicial selection of the rawest forms of patronage appointments and interest-group politics. Since the 1970 s the bar has been a strong voice for pro bono and subsidized legal services.

The bar's laxity, as Rhode says, is rather in its collective incapacity to confront structural problems in its own practices and analyze them in systemic terms, especially if the result is to challenge its core commitments. ${ }^{26}$ Seeing that litigation has become far too expensive for ordinary parties, the bar calls for civility codes for litigators. Seeing that most people are priced out of the legal system, the bar calls for more pro bono service. Seeing that profit-seeking has

24. See Amendments to Ethics 2000 Commission Report 401, House of Delegates Meeting (Aug. 1, 2001), at http://www.abanet.org/cpr/e2k-complete_amend.htm1. (indicating text of proposed revision to rule 1.6 and the deletion of that revision by the House of Delegates).

25. I should clarify here that I am not disputing the propriety of lawyers' helping clients test the limits of the law in open proceedings, or even helping clients publicly and openly conscientiously defy unjust laws. I am talking about advice that surreptitiously subverts the purposes of law.

26. See, e.g., pp. 17, 50, 89-94, 145, 208-09. 
become the guiding ethic in law firms, the bar plaintively asks lawyers to cultivate other values as well. It shrinks from considering the reforms that really might make a difference, such as relaxing unauthorized-practice prohibitions and licensing paralegal providers, or stringent regulation of overbilling. And even confronted with situations in which aggressive zealous advocacy on behalf of clients-stretching the law to its limits-has manifestly contributed to immense social harms, the bar is reluctant to consider moderating its role-morality and ethical rules to take third-party, social interests, or even the effective functioning of the adversary system itself, into account.

The result, it seems to me, is that most effective pressures for reform of the profession will continue to come, when they come at all, from the outside, but that lawyers will continue to resist them.

\section{A CONSTRICTION OF VISION}

The last question that Rhode's account of the legal profession prompts a reader, at least this reader, to ask is, Where are its dreams of greatness? The profession she depicts is strikingly timid, passive, and small-scale in its imagination: "Despite their considerable influence in American life, many lawyers perceive themselves as uncharacteristically powerless in the face of the profession's own problems."27

It has not always been so. America in the early republic faced a vacuum of law, governance, and leadership authority. After the Revolution it turned out that the new states, the new nation, and the new economy required more regular and sustained attention to governance than part-time legislators and juries could provide. America did not have, and did not want, a powerful career civil service. Lawyers stepped forward to fill the vacuum. They had the credentials and the legitimacy because they had articulated the grievances of the Revolution in legal terms; they had drafted the new Federal and State Constitutions, and gradually got them accepted as legal texts subject to lawyers' arguments and judges' interpretations. Lawyers made law and legal discourse and legal procedures into primary modes of governance and disputesettlement in the new nation. They dominated high offices, state and federal, elective and appointive; and (after early experiments with lay judges) achieved a complete monopoly of the upper judiciary-whose professional quality was fairly high, especially considering how little they were paid. Nearly all successful lawyers moved regularly in and out of politics and public service. By the 1830s Tocqueville was calling lawyers the American "aristocracy"more legitimate than a gentry class because they were an aristocracy of merit.

Over the next two centuries, lawyers, on leave from practice, as a sideline to practice, and in the regular course of representing clients, continued to take

27. P. 213. 
the lead in building state structures and legal infrastructures for the new republic. Judges, the advocates who appeared before them, and treatise-writers and code-drafters modernized English common law to adapt it to the new republic and constructed durable systems of federal and state constitutional law, constantly reworking them by amendment and interpretation to meet changing conditions. Lawyers' organizations built professional institutionsregular case reporting, legal journals, bar associations, and law schools. They tried, with partial success, to rescue judicial selection from partisan patronage and make it based on merit.

As political statesmen, lawyers tried, though they ultimately failed, to devise legal solutions to the great political conflicts over slavery and reconstruction of the defeated South. They responded more successfully to the opportunities for leadership opened up by industrialization, which brought with it all the problems of deaths and injuries from accidents, labor conflicts, polluted skies, urban poverty, corruption of government, absorption of new immigrant groups, concentrated economic power, and urgent demands for new systems of regulation informed by educated expertise. Lawyers took the initiative in the Progressive and New Deal reform movements, leading another wave of state-building, this time to construct and staff the commissions and agencies of administrative government. Lawyers on leave from New York City practice dominated the senior policy posts of State, War, and Defense for the entire nineteenth century and for most of the last. They also labored to build an infrastructure of public and private international law to civilize the conduct of commerce, diplomacy, and war, and to protect human rights.

Lawyers were rights activists as well as state-builders. Some rights campaigns were conservative: those of elite judges and lawyers to entrench rights to business property against populist redistributive or regulatory legislation. But legal-rights activists also tried to entrench legal principles against capture by plutocratic private factions as well, to build a system of general equal rights protected against all forms of special-interest rent-seeking. Legal-rights activism was quickly appropriated by other reformers seeking to improve the status and condition of marginalized and subordinated groups: first slaves, women's groups, and labor organizations; later disenfranchised blacks, political and religious dissenters, aliens, and immigrant laborers. In the last century rights activism became a profession of its own. The American Civil Liberties Union built a brilliant record of using the federal courts to prevent persecution of political and religious dissenters. The NAACP Legal Defense Fund deployed a tiny staff of low-paid lawyers in test case litigation in the federal courts to dismantle the system of legally established racial apartheid in the South. In the "Rights Revolution" of the 1960s still more neglected or disrespected groups adopted the civil rights strategy of seeking declarations of rights in the courts, then pressing for legislative and administrative action to make the rights effective. 
Another group of lawyers identified closely with disadvantaged clienteles and saw themselves fighting shoulder-to-shoulder with underdogs to reform society and improve their situation from the bottom up. An entirely new field of endeavor, "poverty law," was opened up in the mid-1960s when President Lyndon Johnson created a federally funded Legal Services Program and foundations led by Ford began making grants to "public interest firms," about half of whom identified the poor as their principal clientele. Most of the new lawyers had an ambitious vision of law as a means of broader social reform, which would work major structural changes in the situation of the poor.

Lawyers in private practice as well as in public office also served as a vanguard of policy entrepreneurs, actively engaged in designing new policies and the legal machinery to implement them. Lawyers of the Progressive period invented the job of legal counsel for the "public interest" group claiming to represent an amorphous and diffuse constituency such as the Public Franchise League or the National Consumers League. Louis Brandeis, a successful corporate lawyer, was also known as the People's Lawyer for his public interest causes. The reformers' ultimate goal was usually to set up an expert commission. They were geniuses at creating publicity. After a scandal revealing some social horror, reformers in collaboration with the muckraking press would persuade legislatures to establish commissions with the power to investigate, hold hearings, and make recommendations. These were mostly staffed by part-time amateur volunteers, usually lawyers. Sometimes they turned into permanent administrative agencies.

In the late 1960s and early 70s the Brandeis model was developed into the role of "public interest" representative in administrative proceedings. The muckraker and consumer lawyer Ralph Nader is the best known and one of the most effective of the "public interest" lawyers that emerged in this period. The mission of the public interest lawyers was to repair glaring defects in political pluralism-to open up the administrative agencies, which had been captured by regulated industries, to the broad constituencies that they were supposed to serve. "The new "public interest" lawyers claimed that other, more diffuse constituencies-TV viewers, lovers of wilderness and the environment, consumers, future generations-also had interests in the administrative decisions. With the help of the federal courts and Congress, public interest lawyers were increasingly permitted to intervene in agency proceedings, and to challenge agency decisions on judicial review.

Leading twentieth-century business lawyers also developed a public account of their social role: that their job was to counsel corporate clients in their long-term interests, and those interests were often to cooperate with government and labor to produce, and comply with, an orderly and socially responsible framework of reasonable regulation and workplace governance. Lawyers who helped businesses fix prices or cheat on taxes or violate safety regulations or produce dangerous products or bribe officials were not really helping their clients-conceived of as entities that had a long-term interest in 
reputations as good citizens and rewarding continuing relations with governments, customers, and local communities. The lawyers' job was to represent the client to the legal system but also to represent the legal system to the client-to help the client to navigate through the maze of law, to minimize the adverse effects of law, but also to stay on the right side of the law. Thus, they thought, private and public roles of lawyering could be merged..$^{28}$

The question Rhode's book inspires one to ask is, What is the broad social vision of today's bar elites? So far as I can tell, there is none. ${ }^{29}$ Elite lawyers have mostly dropped the rhetoric of professional public-serving ideals, and tend to re-characterize their work as that of business service providers, one of several occupations who sell specialized legal-financial services to customers. There remains to them the professional pride of craftsmanship, and pride derived from association with large and important business interests. Probably also they take an abstract vicarious pride in their clients' global mission, assuming the modest role of technical handmaiden greasing the wheels of global capitalism, vaguely presumed to be a generally beneficent force.

The job of continuing the great tradition of republican lawyering has devolved onto specialists on the public side-officials, politicians, government lawyers, public interest lawyers, and academic lawyers. Most public interest work is, however, severely underfunded and much of it devalued. Crippled by its enemies, it limps on with a mostly defensive agenda, trying to prevent gains previously won from being rolled back, rather than articulating broad new programs. The legal specialties that do most of the practical work of protecting the basic constitutional rights of persons-criminal defense and civil rights lawyers-are among those with the least prestige among fellow lawyers.30 Except for some pro bono work, serving the public is not thought to be the

28. The introduction to the ABA's Model Code of 1958 expressed the ethic this way: "Private legal practice, properly pursued, is, then, itself a public service." Lon L. Fuller \& John D. Randall, Professional Responsibility: Report of the Joint Conference, 44 ABA J. 1159,1162 (1958) (emphasis added).

[W] here the lawyer's quiet counsel takes the place of public force.... [b]y reminding him of its long-run costs the lawyer often deters his client from a course of conduct technically permissible under existing law, though inconsistent with its underlying spirit and purpose.... The reasons that justify and even require partisan advocacy in the trial of a cause do not grant any license to the lawyer to participate as legal adviser in a line of conduct that is immoral, unfair, or of doubtful legality.

Id. at 1161 .

29. The one significant exception to this conclusion would be the libertarian lawyers associated with the Federalist Society, conservative think tanks, and public interest law groups, who are also often law firm partners, judges, and (in Republican Administrations) agency officials. These lawyers really do have a broad and far-reaching vision of law and its role in producing a new society and political and moral economy. They think big thoughts and act boldly on them. Their program is, however, so generally congruent with that of elite lawyers' principal business clienteles, who lavishly finance them, that it is difficult to classify it as an independent vision of the public interest.

30. See John P. Henz \& Edward O. LaumanN, Chicago Lawyers: The Social STRUCTURE OF THE BAR 91 (1982). 
concern of the private bar. The firms' governing ideology is the privatized ethic of efficient client service-or the business ethic of profitability. The trade journals of the profession rank firms by average profits-per-partner. Concern for the profession's public functions-especially the function of counseling clients to respect the purposes of the legal framework-has pretty well vanished. If there is an exception to this general inattention to public values and public purposes, it is directed towards other societies, the legal systems of the ex-Communist and developing world, which clearly still need lawyers' help in building and staffing the institutions of the "Rule of Law"-a legal framework for business enterprise and the protection of security and human rights.

My theme is not a lament for everything about the good old days. Many of the bygone bar's public projects seem in hindsight deplorably reactionary and anti-democratic. Even the most idealistic of their projects-pushing for equal rights for subordinated and marginalized groups-have often produced processes so top-heavy with complex, expensive, and intrusive law as to have frustrated supposed beneficiaries. The present order has some good effects: Perhaps it is more efficient than in the old days; perhaps it organizes work better; and at least if the clients have money and clout, it is certainly more competitive and more responsive to their demands. Certainly, it has broken down the old ethnic, racial and gender barriers. Elite law firm practice used to be a practice for white male Protestants only-that system only began to change in the 1970s. Now Catholics and Jews really are equals; women and blacks are hired in numbers proportionate to law school graduates, though, as Rhode among others has shown, they still have trouble making partner.

But one thing has changed, I think pretty clearly, for the worse. Leading lawyers of the Founding Era, through the Civil War, the Progressive Era, the New Deal, the Rights Revolution, and the Great Society all believed that the major social and economic problems of their time, to the extent they could be addressed by means of legal policies and remedies, were their responsibility to help to solve. Some of these were independent lawyers, some worked primarily for businesses, others for labor, others for various social movements. All of them had the biases of their class and clienteles; but they were usually able to see somewhat beyond the immediate interests of class and clients to aim for the construction of legal frameworks they could plausibly claim were in the general interest. Since most high-powered lawyers worked for businesses, their idea of the public interest was sometimes very conservative. But it was usually not narrowly self-serving. Now that clients demand an exclusive loyalty to their interests, and virtually all their lawyers' time, such lawyers have rationalized their adherence to clients' narrow agendas as the highest calling of the advocate.

Some think that this newly constricted vision of the elite profession is all to the good. The old bar's ideology of noblesse oblige, they argue, was elitist, arrogant, hypocritical, and self-deceived. Lawyers have no special mandate or 
capacity for political decisionmaking. Their view of the general interest was always a class interest. If they now claim they are only humble technical servants of clients, that is a role that far better suits their station and talents than that of the lawyer-statesman. ${ }^{31}$

But lawyers at the apex of their profession have hardly renounced their claims to elite incomes, elite status, or elite influence in legal policymaking. Lawyers remain perfectly happy to deploy that influence to advance their own interests and their clients' and to maneuver around the controls of democratically enacted law if it gets in the way. All they have renounced are the social responsibilities traditionally attached to the power and opportunity conferred by elite status. The sense of paralyzed helplessness descends upon them only when they are asked to consider other interests besides their clients' and their own.

To be sure, lawyers no longer have the near-monopoly on public functions that they once had. Many other actors in the public sphere have taken on the roles of policy entrepreneurs, public intellectuals, and part-time officialsforeign policy specialists, journalists, academics, think-tank pundits, economists, and many others. But because institutions for problem-solving and dispute-settling in our society, and the language of civic debate, are so heavily legalized, lawyers are still key actors in public life. The strength, or weakness, of lawyers' civic commitments will continue to make a crucial difference to social outcomes. And this includes the civic commitments of lawyers who represent ordinary clients as well as lawyers for the public interest. The devolution of the public role onto separate corps of officials and other specialists cannot substitute for its performance by private lawyers. Moreover, as the Enron collapse dramatically illustrates, the public framework of law cannot survive the relentless adversarial battering and nibbling away by lawyers unwilling to counsel their clients to respect its basic principles.

The only way in which this excessively privatized and anti-social orientation that we have fallen into can be changed, I think, is basically the same way it has changed before-the ways in which Brandeis and his fellow

31. I have also heard the argument that trust in professions to pursue the public interest has generally fallen so low that professionals cannot regain public leadership roles. This seems to me partly right, but overstated. The world has changed since criticism of professions was at its height (the 1960s and 70s). The left-wing hope that professions could be supplanted by popular judgments of consumers and citizens, and the right-wing hope that adequate professional services could be produced by market forces have both turned out to be illusions. Patients, clients, and the public still must rely on professional judgment that is not readily evaluated by markets, consumers, or regulators. If people do not feel they can trust professionals, the reason is not that they don't want or need to, but that professionals have so often betrayed their trust by not living up to their professions' ideals of altruistic service-and in some cases, such as those of professionals who have wholeheartedly embraced a privatized profit-seeking ethic, by treating that trust as contemptibly naive. Professionals who are perceived to live up to professional ideals, such as Brandeis or (in his heyday) Nader, are greatly admired and readily accepted as leaders. 
Progressives acted to change it earlier in the last century. That is, by means of groups of lawyers, along with others, mobilizing to enable the performance of their public functions-essentially a new Progressive movement, a new Public Interest movement, a new movement to improve access to law for people who cannot afford lawyers, either by subsidizing legal services or by making legal processes cheap and available to people without lawyers.

With respect to serving public goals that are apart and aside from interests of clients, the organized legal profession is probably doing a better job than it ever has-supporting legal services, access to justice (so long as it is provided by lawyers), pro bono commitments by law firms, and the rights of defendants. Where it is not doing so well is in supporting the obligations and the practical capacities of lawyers to take positions, and work for policies, that are in the public's interest but not (at least not immediately) in their clienteles'. For individual lawyers this mostly means taking some small steps: finding and participating in and, if necessary, helping to create collective organizations that can and will push for legal changes that transcend the material interests of lawyers and of powerful client groups.

Now of course there are tremendous practical difficulties in the path of such a mobilization. Many of these are mentioned by other contributors to this small symposium, in particular Geoffrey Hazard, Angela Harris, and Austin Sarat. In somewhat differing ways they all point out that it can be misleading to speak, as Rhode sometimes does (I plead guilty to have done some of this as well), as if there were clear paths to reform in "the public interest" that "the bar" or "the profession" were simply refusing to take, out of self-interest or weakness of will. Hazard and Sarat rightly emphasize that there is neither a unified profession nor a unified view of the public interest, but rather many segments, specialties, and fragments with diverse and sharply conflicting political viewpoints, embedded in different structures of institutions and incentives. Moreover, as Hazard and Harris argue convincingly and at length, the situation that lawyers find themselves in is neither largely of their own making nor exclusively in their power to cure. Harris says that the problems Rhode finds in modern law firm practice-that it is obsessively competitive, bottom-line-driven, rapaciously time-consuming, and indifferent to public values and civic commitments-are merely symptoms of much broader trends, the "turbo-capitalism," uncritical worship of markets, and degradation of civic culture of our times. Hazard adds that other ethical and social features of our legal culture that Rhode thinks problematic, such as the adversary hired-gun ethic and the incredibly uneven distribution of legal services, are products of much larger structures and value-systems, "competitive and individualistic norms," "the political economy of law practice", and the "capitalistconstitutional regime in which modern American law practice is embedded."'32

32. Geoffrey C. Hazard, Jr., Is There an American 'Legal Profession?", 54 Stan. L. Rev. 1463, 1465 (2002). 
These are all valid points, and it is certainly a fair comment on Rhode's project that she could say more, indeed much more, about the general structures, values, and tendencies originating in forces well outside the control of the legal profession(s), which account for lawyers' predicaments and inhibit their capacity to agree and act on any reform program. Still, I don't thinkthough this short essay is not the place to try to develop this argument at length - that these general forces are necessarily as disabling as Rhode's critics imply.

Consider conflict over goals, disputes about what the "public interest" demands. Most lawyers actually do agree on certain basic goals of their profession-for example that the effective functioning of the adversary system requires vigorous representation of all parties, strong professional self-policing, and strong umpires to protect the system against chicanery and sharp tactics. It is just that they are still unwilling to build the institutions and impose the practice requirements that would effectively realize those commitments. In any case, the fact that lawyers often can't agree on reforms is not an impassable barrier: Reforms of any set of professional practices have always come from a small minority of reform entrepreneurs, who were able and willing to mobilize outside interests to help the reform effort.

Or consider some of the other barriers to reform: the current worship of markets, and enduring cultural values such as individualism. Market-worship has, to be sure, prompted cynicism about and adverse treatment of professions as paternalistic monopolies and hastened their deregulation (sometimes with beneficial effects) and assimilation as just another type of profit-making business. And devotion to individualistic values has, perhaps, inhibited lawyers as well as other occupations from developing an ethic of public responsibilities and collective tasks on a scale to parallel their ethic of agency in the service of individual autonomy. But these general values don't, it seems to me, in any way direct lawyers' commitments inexorably in the directions they happen to be currently taking.

A lawyer who seriously believes in capitalism and free markets, for example, ought also be a serious promoter of the legal regimes, institutions, and enforcement capacity that markets require in order to function. The recent experiences of Russia's (and much of the developing world's) efforts to privatize their economies without adequate legal constraints, not to mention some spectacular business failures in our own society, have only reinforced this obvious lesson. Such a lawyer, as I've been trying to suggest here, would not see the act of helping a corporate client conceal its real financial condition from investors and regulators as a promotion of capitalist values, but as a betrayal of them. And though American lawyers have indeed usually been as individualistic as other Americans-and often rather more so, manifesting a stronger commitment than their fellow countrymen to defense of individual persons and individual rights against collective and authoritarian threats-that ideology has not prevented them in the past from taking the lead in building 
state institutions and collective associations and articulating public purposes, often against odds and social pressures at least as imposing as the challenges to which Hazard, Harris, and Sarat point today.

We are, as lawyers, heirs to traditions of grandeur-and sad to say, of squalor as well. Sometimes our profession's claims to serve the public interest have been a complete sham-a thin fig leaf of respectability for lawyers who in fact seek nothing but self-enrichment and disserve even their own clients, or who are merely the pliant tools and mouthpieces of powerful private or official groups or factions. But for their role in state-building, for advocacy to protect dissenters and minorities from persecution, and activism to expand rights through the state and through a more equal and effective system of pluralist representation of interest groups, and finally to build relatively noncorrupt judicial and administrative institutions to oversee all this, American lawyers are admired and imitated by human rights and public interest legal-activist groups all over the world.

So when you hear lawyers say, as these days more and more of them do say, that it is not a private lawyer's job to look after the public's interest, you should know that the most exemplary of American lawyers have not traditionally felt that way, they have not acted that way, and there is no reason why they should act that way now and plenty of reasons why they shouldn't. We should not even dream of abandoning our profession's commitment to the service of public values just as lawyers in societies elsewhere are beginning to take that commitment to heart. 


\section{Reforming Alone?}

\section{Angela Harris*}

In her new book, In the Interests of Justice: Reforming the Legal Profession, Deborah Rhode applies her trademark lucidity and good sense to what she describes as the "conventional wisdom" that today's legal profession is "lost," "betrayed," and "in crisis." Rhode acknowledges that hand wringing about the loss of professionalism in the legal profession has been around for nearly as long as the profession itself, and she is appropriately skeptical about the claim that lawyers are less honest or less civil than they used to be. ${ }^{2}$ There are real problems, nonetheless, and chief among them are a serious lack of access to justice for the non-wealthy and lawyers' own significantly deteriorating quality of life. Rhode sees, these problems as structural in nature, and thus her reform agenda is structural as well:

The public deserves reasonable access to legal assistance and to legal processes that satisfy basic standards of fairness, integrity, and efficiency. It also deserves a regulatory system that can enforce those principles and ensure accountability for the results. Lawyers deserve conditions of practice that will reinforce ethical values in the service of social justice. And they deserve workplaces that encourage equal opportunity, public service, and a decent quality of life. Meeting these challenges will require reforms on several levels. First, we need to harness market forces to promote more and better choices in legal services, legal workplaces, and legal education. Second, we need to provide more effective responses to market failures, which, in turn, means giving the public a greater voice in oversight structures. And finally, we need to socialize lawyers to accept more personal responsibility for their professional actions, their working conditions, and their regulatory processes. ${ }^{3}$

These goals are clearly desirable, and the strategies Rhode advocates to achieve them are sensible and concrete. She proposes changes to professional ethics that would force lawyers to think beyond "some fixed conception of role that denies personal accountability for public consequences or that unduly

\footnotetext{
* Professor of Law, University of California, Berkeley (Boalt Hall). I would like to thank Stephanie Wildman for her comments on an earlier version of this essay.

1. Deborah RHODE, IN THE INTERESTS OF JUSTICE: REFORMING THE LEGAL PROFESSION $1(2000)$.

2. Pp. 11-13.

3. P. 209.
} 
privileges clients' and lawyers' own interests."4 She favors reforms in professional codes, legal standards, and.organizational structures that would curb the excesses of the adversary system, such as experts for hire, the coaching and the victimization of trial witnesses, and the immoral or outright illegal behavior of lawyers themselves. ${ }^{5}$ She suggests ways to alter the incentives for firm lawyers to reward themselves handsomely at the expense of clients, ${ }^{6}$ and ways to "create a culture of commitment to public service" in law schools. ${ }^{7}$ As Rhode acknowledges, it cannot be assumed that this myriad of structural changes will eliminate all greed, injustice, dishonesty, and incivility in the legal profession, but her proposals are as good a place as any to begin.

Ironically, Rhode argues, the biggest obstacle to reform has been the American legal profession's "own unwillingness to come to terms with what the problems are."' This denial stems from "two central conflicts: the tensions between lawyers' economic and non-economic interests, and the tensions between professional and public interests. Money is, of course, at the root of both conflicts." Lawyers want it all: high salaries and moral respectability; justice for all and a monopoly on the provision of legal services; public trust and no pesky regulation or public accountability. Rather than acknowledge the reality of conflict among these goals, Rhode charges, the organized bar undertakes feel-good public relations campaigns and issues moral exhortations. As in her famous analysis of institutional sex discrimination-the "no-problem problem"10_-Rhode thus ultimately calls lawyers on their collective denial and, hence, complicity.

I wonder, however, whether one reason these reforms or others have not yet occurred - and why the organized bar seems to perceive a crisis yet also seems paralyzed in the face of it-is not only lawyers' own reluctance to face facts and make hard choices, but the headwinds against which reformers must struggle. These include economic "turbo-capitalism" and the slow degradation of a broader civic culture, and as a result of their turbulence, Rhode and other sympathetic observers of the profession may find themselves reforming alone.

I.

The lawyers with corporate clients who make the most money and have the most prestige in the profession-those whom Rhode identifies as standard-

4. P. 67.

5. Pp. 93-96.

6. Pp. 178-183.

7. Pp. 205-206.

8. P. 13.

9. P. 13.

10. See Deborah L. Rhode, The "No-Problem" Problem: Feminist Challenges and Cultural Change, 100 Yale L.J. 1731 (1991). 
setters for the profession ${ }^{11}$ - have recently been caught up in a period of rapid marketization of their practice. Dennis Curtis ably summarizes the conditions now facing partners and associates in large law firms:

From recent graduates and popular culture, a somber view emerges, in which the economics of firm practice create a focus on the "bottom line" leading to relaxation of ethical standards, requirements for increased billable hours, erosion of loyalty toward both associates and partners, impersonal workplace relationships, and a reduction of the time and effort that was once devoted to training associates to be competent lawyers. The idea of a client having a longstanding relationship with one firm has lessened, if not altogether disappeared. The relationship between lawyer and client has become a series of business dealings. Single transactions with a variety of law firms allow clients to compare expertise, shop and bargain for lower rates, and demand immediate response. As one lawyer ruefully told me, "clients know what we can do and how fast we can do it, and think nothing of imposing deadlines that make us worry about whether we're providing the best service to them." The sense of being exploited by clients is mirrored by a willingness to exploit; the prevalence of single-transaction relationships also encourages lawyers to view clients as short-term revenue sources. ${ }^{12}$

The consequences of marketization are many. Curtis observes that prestige is increasingly measured only by "billable hours, partner profits, and market share in a practice area or in a city" rather than "peer recognition, participation in bar association activities and projects, especially those designed to provide access to justice for those unable to afford it, and leadership of nonlaw-related civic groups such as symphonies, libraries, and museums."13 Technological innovations mean that "people can work and be accessible around the clock and that revisions are almost always possible, thereby increasing the work to be done."14 Curtis was surprised both by lawyers' attention to the accounts of big deals, big cases, and big money found in media outlets such as The American Lawyer, the National Law Journal, and Court TV, and by the resentment managing partners felt about the unwavering focus of these accounts on the "bottom line."15 Such stories about the business aspect of law, though providing useful information, also exacerbate a sense of competition among lawyers and increase the focus of that competition on money.

11. P. 24.

12. Dennis Curtis, Can Law Schools and Big Law Firms Be Friends?, 74 S. CAL. L. REv. 65, 69-70 (2000) (footnotes omitted); see also Lisa G. Lerman, Blue-Chip Bilking: Regulation of Billing and Expense Fraud by Lawyers, 12 GEO. J. LEGAL ETHICS 205, 219 (1999) (discussing the profession's "[p]reoccupation with profit" and the "rising dominance of income generation").

13. Curtis, supra note 12 , at 70 .

14. Id.

15. Id. 
This is "turbo-capitalism" for lawyers, spurred both by the increasingly intense competitive pressures facing corporate clients in a rapidly "globalizing" world and by the technological and institutional changes noted by Curtis that affect lawyers directly. ${ }^{16}$ In this new environment, there is little or no institutional space for pro bono work and other contributions to the public good; the financial bottom line is necessarily the watchword. Thus the problems that leaders of the profession decry, such as the lack of access to justice for the poor, the decline in pro bono work generally, and the (debatable) decline in civility may be exacerbated by, if not solely caused by, the reshaping of the profession around market values.

Marketization has also meant a simultaneous dramatic rise in salaries and a dramatic increase in time pressure for firm lawyers. Rhode describes how firms have found themselves trapped in the spiral of escalating billable hour requirements and escalating salaries for promising entry-level associates:

The irrationality of current compensation structures began, rationally enough, when competition for the ablest new associates pushed starting salaries well above what hourly billing rates justified. These raises have forced compensation increases for other attorneys as well, a problem compounded by salary wars with accounting firms and internet companies. Because competitive pressures have prevented comparable increases in billing rates, the choice has been either to decrease partner profits or raise associates' workload. Predictably, most partners have opted for the latter choice. And they have blamed the oppressive schedules that result on associates who seem to prefer high salaries to more humane working conditions. Managing partners often report experiences similar to the one that Walt Bachman describes in Law v. Life. When his firm attempted to freeze both hours and starting salaries, applicants flocked to other firms. Many of these young associates were predictably miserable when they got there. ${ }^{17}$

The insistence of associates on higher salaries rather than more time is understandable; in a market culture, the coin of the realm is, well, coin. But as Rhode points out, associates' unwillingness to compromise on salary ensures that something has to give, and that something is activities-including pro bono work, sleep, and reproduction-that do not contribute to the bottom line. As Rhode recognizes, this is bad not just for individual lawyers, who after all can choose some other profession, but for the positive externalities that the practice of law is said to generate:

A preoccupation with the bottom line has squeezed out other values that are central to a satisfying professional life. It has preempted time not only for families but also for community involvement and cultural pursuits. In the process, it has stunted opportunities for lawyers to develop the broad-gauged

16. See EDWARD LUTTWAK, TuRBo-CAPITALISM: WINNERS \& LOSERS IN THE GLOBAL ECONOMY (2000) (describing the effects of increased coordination of labor and financial markets across national boundaries, improvements in information technologies, and a new enthusiasm for "free trade" ideologies around the world).

17. P. 36. 
experience that qualifies them for counseling and leadership roles. And it has foreclosed opportunities for the pro bono legal work that lawyers traditionally have ranked among their most satisfying professional experiences. ${ }^{18}$

The phenomenon of spiraling salaries at the top is not, however, unique to big firm lawyers. Economists Robert Frank and Philip Cook argue that across a wide variety of labor markets, technological changes related to information processing and dissemination have produced "increasing leverage for the talents of those who occupy top positions and correspondingly less room for others to find a lucrative niche."19 They have dubbed this phenomenon the "winner-take-all" market, and they argue that such markets have contributed to dramatic earnings inequality in a variety of American occupations, from corporate management to sports to the media to the professions. Moreover, Frank and Cook argue, drawn by the promise of vast sums of money being made by a few, far more people flock to the field than is socially useful. Thus, the ever-rising salaries for the best and the brightest in large law firms means too many people going to law school instead of going into less lucrative but more socially beneficial careers; the losers include both the disappointed majority of lawyers who will never see six-figure salaries and society as a whole.

Similarly, the culture of cell phones and twenty-four/seven access, and the ensuing shrinking of leisure time, pervades the working life of the white-collar managerial classes in general, not just the working lives of lawyers. For example, economist Juliet Schor argues that an insidious cycle of "work and spend" has taken hold in American society that only bold public policy initiatives can break. 20 Because workers in many occupations, not just law, have chosen more money rather than more leisure as the reward for productivity, and because, from an employer's perspective, working the same bodies harder rather than recruiting more bodies is a better strategy for increasing labor input, Americans across the board are working longer hours than ever before. Schor is troubled not only by Americans' lack of time for stopping and smelling the roses, but by the compensatory spending on luxury

18. P. 37.

19. Robert H. Frank \& Philip J. COOK, The WINNER-TAKe-All SOcIETY: How MORE AND MORE AMERICANS COMPETE FOR EVER FEWER AND BIGger PRIZES, ENCOURAGING ECONOMIC WASTE, INCOME INEQUALITY, AND AN IMPOVERISHED CULTURAL LIFE 8 (1995).

20. JULIET B. SCHOR, THE OVERWORKED AMERICAN: THE UNEXPECTED DECLINE OF LEISURE 142 (1992) ("Changes must be made on a number of fronts: altering employers' incentives; improving wages for the lowest-paid; creating gender equality; preempting the automatic spiraling of consumption; and throughout, establishing time's value independent of its price, so that it can no longer be readily substituted for money."). Judging by the recent exhortations by the Bush II administration to consume more in the name of patriotism following the events of September 11,2001 , it seems unlikely that government efforts to break the cycle of work-and-spend are forthcoming any time soon. 
items by the upper-middle class, which, she argues, reduces the funds available for public services. ${ }^{21}$

As Rhode recognizes, a sensible public policy response to these trends is to consider reforms that would both relieve the time squeeze for lawyers and redistribute legal resources from the wealthy to the less wealthy, from private to public concerns. However, to do this lawyers must struggle against the headwinds not only of their own profession, but of American upper-middle class life generally. As long as the "ideal worker" is a person with no family responsibilities, part-time and family leave policies threaten to create secondclass status for the people who take advantage of them. ${ }^{22}$ Moreover, to break the cycle of positional arms races, some significant regulatory interventions are required; yet, we live at a moment when "free markets" and "privatization" are being touted as the answer to social ills of all sorts, from increased global competition to rising health care costs.

Market forces and market failures are driving the current ills of the legal profession. Like medicine, law is inherently an imperfect market. Just as we don't like the idea of children dying in the streets because their parents lack the money for emergency services, we don't like the idea of people being sent to the electric chair after trials during which their lawyers slept. Some minimal level of access to justice for all is a public good, just as some minimal health care for all is a public good: The basic social trust needed for both capitalism and democracy will thrive in a society where the legal system is available to publicize and redress wrongs. These goods will not be provided in a completely free market, and the bar's self-organization as a "profession" has traditionally responded with codes of ethics and habits of public service. This culture of non-market values, combined with modest competition to provide legal services, has arguably provided, in a rough way, both market pressures necessary to produce high-quality services and some cultivation of the public goods that cannot be provided by an entirely "free" market. As a new wave of turbo-capitalism sweeps the profession, however, increasing exhortations to lawyers to treat one another better and to serve the needy are no longer enough.

\section{As Schor puts it:}

There is ... a boomerang effect on the public purse and collective consumption. As the pressures on private spending have escalated, support for public goods, and for paying taxes, has eroded. Education, social services, public safety, recreation, and culture are being squeezed. The deterioration of public goods then adds even more pressure to spend privately. People respond to inadequate public services by enrolling their children in private schools, buying security systems, and spending time at Discovery Zone rather than the local playground.

Juliet B. SCHOR, The OVERSPENT AMERICAN: UpSCAling, DOWNSHIFTING, AND THE NEW CONSUMER 21 (1998).

22. See JOAN WILLIAMS, UNBENDING GENDER: Why FAMILY AND WORK CONFLICT AND WHAT TO DO ABOUT IT 1 (2000) (arguing that market work has been organized around "the ideal of a worker who works full time and overtime and takes little or no time off for childbearing or child rearing"). 
Rhode may be right that more regulation of the right kind is necessary to both encourage the virtues of markets and constrain their flaws. The pressures and ideologies of turbo-capitalism, however, mean that reforms that involve the most significant interventions into markets-like the idea that bar associations should require all lawyers to contribute a specified amount of time to pro bono service $^{23}$ - are likely to be the least successful.

II.

Rhode's call for meaningful reform of the legal profession also comes at a time when not only the profession's own civic culture, but the larger political and civic culture with which it is intertwined, are on the ropes. One of the effects of turbo-capitalism for lawyers has been less time not only for pro bono work but for service to the profession itself. Rhode sees clearly that these losses to the profession are significant; again, however, the problem seems larger than just the need for lawyers to roll up their sleeves.

Like structural economic factors, structural social and political factors serve as headwinds against which reformers must struggle. Thus, for example, in his jeremiad, Who Will Tell the People, William Greider bemoans the erosion of citizen-based politics in the United States. ${ }^{24}$ Greider argues that in contemporary American political life, citizens have been pushed into two narrow roles: spectators, momentarily entertained or outraged by scandals, who speak primarily through opinion polls; and "special pleaders," organized through professional groups that lobby for this or that narrow interest.25 Missing here is the middle ground where citizens and the people who represent them can engage in mutual dialogue about issues that go beyond immediate self-interest.

In the contemporary political climate, lawyers have an advantage over ordinary citizens, of course: They have the expertise, the technical savvy, and the connections to influence political actors. But without meaningful political connections to ordinary laypeople, professional reforms pushed by lawyers are likely to favor the already-privileged: powerful corporate clients or the elite within the legal profession itself. In such a climate, who will fight the good fight in favor of proposals like mandatory malpractice insurance ${ }^{26}$ and disclosure of fee and billing arrangements ${ }^{27}$-proposals that would benefit the public but for which legal elites tend to have little enthusiasm?

23. P. 46.

24. William Greider, Who Will Tell the People: The Betrayal of american DEMOCRACY (1992).

25. Id. at $18-19$.

26. See p. 167.

27. See p. 180. 
Those arenas in which public policy is made are increasingly associated with for-profit rather than not-for-profit organizations. For example, Greider suggests that the logical goal for public-spirited large firm attorneys has become in-house representation of large multinational corporations. He notes that Benjamin Heineman, former managing partner of the Washington office of Sidley \& Austin, and Philip A. Lacovara, former Watergate prosecutor, subsequently joined General Electric (GE) for the public policy opportunities it offered. ${ }^{28}$ As Greider argues:

GE is an outstanding prototype of the modern corporation doing politics, since its product lines and corporate interests intersect with practically every dimension of the federal government's decision making. GE makes the things that government buys but also the things that government regulates and licenses: light bulbs and locomotives, jet engines and nuclear bombs, TV broadcasting and nuclear-power plants and financial services.

....

General Electric also tries to act like a mediating institution-speaking on behalf of others. GE, like many other companies, assumes the burden of representing various groups of other citizens in politics-workers, consumers, shareholders, even other businesses and the well-being of Americans at large. GE has the resources to develop and promote new political ideas and to organize public opinion around its political agenda. It has the capacity to advise and intervene and sometimes veto. It has the power to punish political opponents. It also has the sophistication to lend its good name to worthy causes, such as the Urban League, only remotely related to the company's profits. $^{29}$

What does the replacement of citizen-based politics with corporate-based politics mean for reform of the legal profession? One implication is that professional reforms in which corporations have a driving interest are more likely to emerge and to succeed than reforms which would primarily benefit the public at large, or poor, working-class, and middle-class consumers of legal services. Another implication is that the heavy hitters in the profession who have an interest in public policy are likely to be drawn to influencing the global economy on behalf of behemoths like GE before they are drawn to developing models for effective self-representation by low and middle-income court users. ${ }^{30}$

Greider's point has to do with electoral and participatory politics. Sociologist Robert Putnam tells us, however, that in the last third of the twentieth century there has been a dramatic decline underway in all sorts of civic organizations, from bowling leagues to parent-teacher associations. ${ }^{31}$ One

28. GREIDER, supra note 24 , at 332-33.

29. Id. at 335-36.

30. P. 140.

31. See Robert D. Putnam, Bowling Alone: The Collapse and Revival of AMERICAN COMMUNITY (2000). Putnam argues: 
example in Putnam's data is the American Bar Association (ABA). As Putnam acknowledges, total membership in the ABA quadrupled from 1945 to 1965 , and then tripled again by $1991 .^{32}$ This seeming success story is mirrored in the stories of other professional organizations that have enjoyed burgeoning membership in the past few decades, such as the American Medical Association, the American Institute of Architects, and the American Society of Mechanical Engineers. Yet, Putnam argues, a closer look at the numbers reveals declining membership rates in relation to the available pool of members, a downtum that has become marked since the 1960 s and 1970 s. $^{33}$ Thus, while the absolute number of members of the ABA and similar organizations has grown, membership in the $A B A$ as a fraction of employed lawyers has declined since $1977 . .^{34}$

Putnam's data also suggest a transformation of many erstwhile publicminded organizations from grassroots membership organizations to professionally run and staffed groups with little policy input from members. ${ }^{35}$ Thus, it is not only that fewer people are joining professional, civic, and special-interest groups; it is also that their participation increasingly takes the form of simply paying dues and receiving a newsletter, rather than the kind of face-to-face interaction that produces social capital. Putnam does not explore the question of whether membership in the ABA has become more passive in this way, but given the necessities of turbo-capitalism, it is hard to imagine that it has not.

Putnam argues that low levels of "social capital" (defined as "connections among individuals-social networks and the norms of reciprocity and

Thin, single-stranded, surf-by interactions are gradually replacing dense, multistranded, wellexercised bonds. More of our social connectedness is one shot, special purpose, and selforiented.... Large groups with local chapters, long histories, multiple objectives, and diverse constituencies are being replaced by more evanescent, single-purpose organizations, smaller groups that "reflect the fluidity of our lives by allowing us to bond easily but to break our attachments with equivalent ease." Grassroots groups that once brought us face-to-face with our neighbors, the agreeable and disagreeable alike, are overshadowed by the vertiginous rise of staff-led interest groups built to represent our narrower selves. Placebased social capital is being supplanted by function-based social capital. We are withdrawing from those networks of reciprocity that once constituted our communities.

Id. at 183-84.

32. Id. at 83.

33. Id. at 84, fig. 15, app. III. According to Putnam's data, all the professional organizations he studied began to decline after a post-World War II boom:

First to reach its peak and begin to decline was the American Medical Association (AMA) in 1959, followed by the American Dental Association and the American Institute of Architects (both in 1970), the American Bar Association (ABA) in 1977, and finally the American Institute of Certified Public Accountants in 1993 ... [E]ven in this area of apparent growth, we see the same pattern of growth in sociability during the first two-thirds of the century, followed by sudden stagnation and then decline during the last third.

Id. at $84-85$.

34. See id. app. III.

35. See id. at 51-52. 
trustworthiness that arise from them") ${ }^{36}$ are associated with a cascade of specific negative effects, from unsafe streets to elevated levels of clinical depression. ${ }^{37}$ On the positive side, he argues that social capital has many beneficial effects, at least three of which seem relevant for Rhode's project. First, social capital helps people resolve collective action problems: when people share social norms of mutual aid, free-riding is reduced. ${ }^{38}$ Second, social capital reduces transaction costs: "There is no need to spend time and money making sure that others will uphold their end of the arrangement or penalizing them if they don't." 39 Third, social capital increases a distinctive set of virtues, such as tolerance and empathy for others.

Each of these beneficial effects seems to speak to the predicament of the American legal system as described by Rhode. The extensive gap between lawyers' professed aspirations toward public service and the reality of minimal involvement can be described as a free-rider problem. ${ }^{40}$ Higher levels of professional trust, particularly between lawyers and non-lawyer specialists, would, Rhode argues, result in more services and lower prices for American consumers. ${ }^{41}$ Finally, the virtues of empathy for others and a sense of shared fate would surely foster the diversity-related initiatives that Rhode argues are sorely needed both in law practice and in legal education. ${ }^{42}$ Rhode concludes that "The central challenge for the legal profession is how to strengthen a sense of ethical obligations and to inspire a richer sense of what they demand in practice.... Lawyers' primary responsibility should run to the system of justice and to the core values of honesty, fairness, and good faith that sustain it."43 Putnam's analysis tells us that fostering this sense of ethical obligation and civic virtue is a challenge not only for the legal profession, but for American society generally.

Situating the troubles of the legal profession within this larger context does not mean that Rhode's proposed reforms are not a good idea, or that none of them can be accomplished. It does, however, cast doubt on whether it is solely a failure of will on the part of attorneys that is to blame for the profession's failure to reform itself, or whether lawyers' own denial has converged with

36. Id. at 19.

37. Id. at 307-18 (arguing that social capital contributes to safe and productive neighborhoods); $i d$. at 326-35 (arguing that social capital contributes to individual health and happiness).

38. Id. at 288 .

39. Id.

40. P. 27 (describing the gap between aspiration and reality).

41. See Pp. 135-41 (arguing that the public needs access to a diversity of legal services, including self-help and assistance from non-lawyer providers such as real estate brokers, accountants, paralegals, and legal secretaries).

42. $\mathrm{Pp}$. 38-44 (arguing that increased racial and gender diversity would help the profession); pp. 192-96 (arguing for the need to foster diversity in legal education).

43. P. 213. 
larger political, economic, and social trends. It may be that the troubles of the justice system are the troubles of American society in miniature. Just as Americans tend to turn social problems into legal problems, the difficulty we seem to be having reforming our legal profession may be a reflection of our deeper struggles with rapid economic change and growing social malaise.

\section{III.}

Along with my then-colleague Stephanie Wildman, I recently taught a seminar on "Law and Social Justice" that examined the practice of lawyering in the service of "social justice" goals, however defined. One of the most striking observations to come from teaching that course was the increasing polarization of the student body between those who had committed themselves to a "public interest" career and those who were choosing corporate jobs (whether out of a genuine desire to do such work, the notorious desire for "training," the pressure of student loans, ${ }^{44}$ or because offers from large firms-like large salaries among associates-are the coin of the realm in the law student hierarchy of prestige). As entry-level associate salaries skyrocket and law school tuition inexorably rises, public-interest-bound students feel increasingly caught in an untenable material situation, and also feel put on the psychological defensive. As Robert Kuttner notes, "[w]hen everything is for sale, the person who volunteers time, who helps a stranger, who agrees to work for a modest wage out of commitment to the public good, who desists from littering even when no one is looking, who forgoes an opportunity to free-ride, begins to feel like a sucker." ${ }^{245}$

One reaction to feeling like a sucker is a Nietzschean strategy: Socialjustice-oriented students, in order to justify their choices to themselves, their peers, their class "reference group,"46 and their worried parents, increasingly identify themselves as morally good and their big-firm-bound friends as morally evil. This moral stance reassures social-justice-minded students that they are doing the right thing, but it has the drawback of permitting, even encouraging, budding corporate associates to stop worrying about pro bono work or professional ethics, and permitting or encouraging their senior partners to do the same. Another reflection of the seemingly forced choice between doing good and doing well is the relegation of public interest to upper-middleclass students, who feel less family pressure, financial pressure, and social expectation to do well and can concentrate on doing good. A cultural result of

44. But see Lewis A. Kornhauser and Richard L. Revesz, Legal Education and Entry into the Legal Profession: The Role of Race, Gender, and Educational Debt, 70 N.Y.U. L. Rev. 829 (1995) (arguing that the career choices of law school graduates through the early 1990 s was not affected significantly by educational debt).

45. ROBERT KUTTINER, EVERYTHING FOR SALE: THE VIRTUES AND LIMITS OF MARKETS $62-63$ (1997).

46. See ScHOR, supra note 21. 
lawyers' turbo-capitalism and the absence of a strong political and civic culture to counter it, then, may be an increased sense of division among lawyers, with the public interest lawyers taking the full burden of responsibility for the public good and that burden slipping from the shoulders of the large corporate firms. ${ }^{47}$

All is not lost, of course. Not all of the results of increased marketization are bad. Technological improvements have no doubt increased efficiency and perhaps boosted the quality of legal services. Rhode argues convincingly that loosing the profession's monopoly stranglehold on the practice of law has the potential to bring legal services to more consumers:

The diversity in American legal needs argues for greater diversity in educational and regulatory structures. Law schools should offer a broader range of degree programs, including shorter training for limited practice specialties. Graduates of these limited degree programs, along with other qualified non-lawyers, should be permitted to offer routine services, subject to ethical requirements regarding competence, conflicts of interest, confidentiality, malpractice insurance, and so forth..$^{48}$

Along with more choices should come more and better information, and regulation to protect clients who are inherently at an information disadvantage. 49

Nor is the chaos we now see in large law firms the end of the story. As Dennis Curtis notes, we know very little about the internal financial structure of law firms. ${ }^{50}$ Perhaps they are in a period of "structural adjustment" that will ultimately result in more rational and efficient practices. Perhaps, for example, as large law firms come to increasingly resemble the large corporations they serve, they will undergo the same management revolution, seeking to increase loyalty and productivity by making law firms a happy place to live as well as work..$^{51}$ New ways to organize the practice of law may emerge that link

47. It may be that this polarization will have some effect on the racial composition of public interest lawyers as well. There is anecdotal evidence at my school of racial polarization among students, with public interest-identified students more likely to be white and students of color more likely to cite financial need as a reason for rejecting social justice work. It is not clear, however, what the racial effects in the larger profession might be of increased polarization between those who seek to do well and those who seek to do good. Even if it is true that attorneys of color are likely to seek higher-paying career paths, Rhode points out that women and minority attomeys are by no means succeeding in large law firms. Pp. 38-39.

48. Pp. 209-10.

49. See pp. $210-11$.

50. Curtis, supra note 12 , at 69 .

51. For a review of management trends, such as Total Quality Management, that have accompanied the new "psychological contract" in the corporate world, see Katherine V.W. Stone, The New Psychological Contract: Implications of the Changing Workplace for Labor and Employment Law, 48 UCLA L. REV. 519 (2001). For an argument that for some employees of large corporations, the workplace has become a haven away from the stresses of family life, see ARLIE HOCHSCHILD, THE TIME BIND: WHEN WORK BECOMES HOME AND HOME BECOMES WORK (1997). 
associates' desires to have a life with their desires to do good as well as do well.52 For now, though, part of the story is not just the need for reform that Deborah Rhode ably sketches, but why such reforms seem so difficult to achieve.

52. For example, James Regan argues for a new experiment in cross-subsidy: the "50$50 \mathrm{firm}$ " that would seek an equal balance between paid and pro-bono work. See James Regan, How About a Law Firm Where People Actually Want To Work?: A "Professional" Law Firm for the Twenty-First Century, 69 ForDHAM L. REv. 2693 (2001). 